\title{
Reasons for job separations in a cohort of workers with psychiatric disabilities
}

\author{
Judith A. Cook, PhD; ' Jane K. Burke-Miller, PhD \\ Department of Psychiatry, University of Illinois at Chicago, Chicago, IL
}

\begin{abstract}
We explored the relative effects of adverse working conditions, job satisfaction, wages, worker characteristics, and local labor markets in explaining voluntary job separations (quits) among employed workers with psychiatric disabilities. Data come from the Employment Intervention Demonstration Program in which 2,086 jobs were ended by 892 workers during a 24 mo observation period. Stepped multivariable logistic regression analysis examined the effect of variables on the likelihood of quitting. Over half (59\%) of all job separations were voluntary while $41 \%$ were involuntary, including firings (17\%), temporary job endings (14\%), and layoffs (10\%). In multivariable analysis, workers were more likely to quit positions at which they were employed for $20 \mathrm{~h} / \mathrm{wk}$ or less, those with which they were dissatisfied, low-wage jobs, non-temporary positions, and jobs in the structural (construction) occupations. Voluntary separation was less likely for older workers, members of racial and ethnic minority groups, and those residing in regions with lower unemployment rates. Patterns of job separations for workers with psychiatric disabilities mirrored some findings regarding job leaving in the general labor force but contradicted others. Job separation antecedents reflect the concentration of jobs for workers with psychiatric disabilities in the secondary labor market, characterized by low-salaried, temporary, and part-time employment.
\end{abstract}

Key words: adverse working conditions, job satisfaction, job separation, psychiatric disability, recovery, return-to-work, serious mental illness, supported employment, vocational rehabilitation, voluntary separation.

\section{INTRODUCTION}

Employment for people with psychiatric disabilities is a complex phenomenon influenced by a multitude of fac- tors, including labor market conditions, individual work environments, worker characteristics, and public disability policies [1]. Although effective models of vocational rehabilitation have been developed to help people with psychiatric disabilities obtain employment, most jobs that result are low-wage, part-time, and temporary [2-3]. Prior research indicates that job separations of workers with serious mental illness are typically voluntary, yet high proportions of workers quit without having obtained another position [4-5]. Given the known therapeutic and economic benefits of employment for people with psychiatric disabilities [6-7], as well as their contributions to national economies [8-9], more information about the causes and antecedents of voluntary job separation is needed to inform return to work and job retention interventions as well as public disability employment policies. We combine

Abbreviations: CMHS = Center for Mental Health Services; DOT = Dictionary of Occupational Titles; DSM-IV = Diagnostic and Statistical Manual of Mental Disorders-4th edition; EIDP = Employment Intervention Demonstration Program; IRB = institutional review board; NIDILRR = National Institute on Disability, Independent Living, and Rehabilitation Research; SAMHSA = Substance Abuse and Mental Health Services Administration; SSA = Social Security Administration; SSDI = Social Security Disability Insurance; SSI = Supplemental Security Income; UIC = University of Illinois at Chicago; VR\&E = vocational rehabilitation and employment.

*Address all correspondence to Judith A. Cook, PhD; Department of Psychiatry, University of Illinois at Chicago, 1601 W. Taylor St, 4th Floor, M/C 912, Chicago, IL 60612; 312-355-3921; fax: 312-355-4189. Email: jcook@uic.edu http://dx.doi.org/10.1682/JRRD.2014.10.0260 
approaches from labor market research, human resource management, and psychiatric rehabilitation to assess multiple antecedents of voluntary job separation in a large cohort of adults with psychiatric disabilities.

Prior research on job separations among this group of workers has not always used commonly recognized definitions of job ending statuses, impeding the comparison of results across studies. One example is the practice of combining separation statuses into categories deemed "unsatisfactory," such as collapsing firing and quitting without having another job $[5,10]$ or combining firing with quitting due to poor performance or not liking the job [11]. In some but not all cases, enough information is provided to reconstruct job separation categories that mirror those used in labor force research. Here, we see that quitting for any reason is the most common separation status reported for 50 to 63 percent [4-5,10,12]. Firing is less common, reported for 8 to 19 percent $[4-5,10]$. A noteworthy proportion of separations are due to the ending of temporary jobs, reported for 10 to 33 percent [5,10-12]. Finally, occurrence of separation due to lay-off is less common, varying from 2 to 16 percent [4-5,10,12].

Research regarding the reasons given for different job ending statuses has found that most voluntary job separations are due to poor job performance, job dissatisfaction, lack of work motivation, poor labor force attachment, and worker stress or other mental health concerns. In a population of 143 adults with severe mental illness who obtained jobs through supported employment programs, Becker et al. found that only 13 percent of quits were followed by workers moving on to other employment [5]. Factors associated with job separations that were followed by unemployment included less recent work experience, interpersonal problems, problems related to mental illness, poor job performance, and job dissatisfaction. In a study of 252 adults with severe mental illness participating in vocational rehabilitation programs, Cook found that only 11 percent of workers quit to take an independent job [4]. Factors associated with job separations included inability to perform job tasks, stress, and low motivation to hold the job. In a study of 108 employed adults with psychiatric disabilities receiving ongoing vocational support services [11], 45 percent were fired or quit within 6 mo of placement due to job dissatisfaction or inability to perform the job. Predictors of job separation were lower hourly wage, temporary work, and more employment support hours. Most separations occurred in the first month of employment, with reasons for voluntary separations including quitting due to inability to perform job tasks, job dissatisfaction, and exacerbation of mental health condition.

There is ample evidence that the labor market position of people with psychiatric disabilities is systematically unfavorable relative to that of nondisabled individuals, with high levels of exclusion, unemployment, underemployment, and wage and other forms of discrimination [1]. Jobs held by people with psychiatric disabilities tend to be characterized by low wages and high turnover [11]. However, low-wage, low-skill jobs are not unique to people with psychiatric disabilities. In the U.S. labor market, low-wage jobs are part of what is considered the secondary labor market, characterized by high job instability and little opportunity to ascend career ladders, few fringe benefits, and more gender and racial discrimination than in the primary labor market [13]. By some analyses, the secondary labor market accounts for almost half of all jobs [14], and labor force bipolarization has been growing over the past four decades [15]. This is mirrored in research on jobs held by workers with disabilities [16]. For example, a study of jobs held by workers following vocational rehabilitation found that the large majority were in the secondary labor market, clustered primarily in two types of occupations: food service (48.7\%) and custodial (35.4\%) [17].

Job turnover is frequent in the secondary labor market, especially in industries where disadvantaged workers tend to find employment, such as retail trade and business services [18]. Lane points to lower job attachment among younger workers, unmarried workers, and female workers as a reason for higher quit rates in these groups [18]. Voluntary separations among low-wage workers are detrimental to both employers, who incur rehiring and training costs, and employees, who lose income and opportunities for job advancement [19].

Labor economists have focused on wage as a predictor of voluntary job separations, and more recently, researchers have borrowed from the human resource management literature to also include job satisfaction and consideration of job "disamenities" or adverse working conditions [20]. Job disamenities are job-specific and worker-perceived factors that lead to job dissatisfaction that in turn leads to voluntary job separations, regardless of the effects of wages, individual worker characteristics, industry features, and local unemployment rates [21].

Given the complexity of the context in which jobs and job separations occur for people with psychiatric 
disabilities, we applied Böckerman and Ilmakunnas' model to examine antecedents of voluntary job separations not only in terms of job holder characteristics but also aspects of working conditions and work attitudes [21]. These domains include adverse working conditions or job disamenities (employment that is part-time; that is temporary; with no fringe benefits; with no direct relationship with employers; and that is demanding physically, mentally, and interpersonally), job dissatisfaction, wages, worker demographic and clinical characteristics, and local labor market conditions. We used job separation data from the Employment Intervention Demonstration Program (EIDP), a multisite study conducted from 1996 to 2001 that was designed to generate knowledge about effective approaches for enhancing employment among adults with serious mental illnesses [22]. We hypothesized that antecedents of voluntary job separations would include job disamenities, job dissatisfaction, and low wages. We also expected that voluntary separation would be greater among younger workers and those with less education.

\section{METHODS}

\section{Study Background}

The EIDP was a 5 yr study of supported employment programs for people with severe mental illnesses conducted in eight states (Arizona, Connecticut, Maine, Maryland, Massachusetts, Pennsylvania, South Carolina, and Texas) and funded by the Center for Mental Health Services (CMHS) of the Substance Abuse and Mental Health Services Administration (SAMHSA) [23]. By means of a Cooperative Agreement funding mechanism, researchers, Federal personnel, and policy makers developed and implemented a Common Protocol and Documentation [24], uniform data collection methods, and a hypothesis-driven analysis plan. This effort was led by a Coordinating Center based at the University of Illinois at Chicago (UIC) Department of Psychiatry in partnership with the Human Services Research Institute in Cambridge, Massachusetts.

Study participants were recruited from existing clinical populations via case manager referral, self-referral, word-of-mouth, and newspaper advertisements (1 site). Participants met the following inclusion criteria: $\geq 18 \mathrm{yr}$ old at the time of study enrollment, willing and able to provide informed consent, interest in working, and an axis I Diagnostic and Statistical Manual of Mental Disorders-4th edition (DSM-IV) [25] diagnosis of mental illness accompanied by severe or moderate functional impairment. Subjects were recruited in waves, with data collection beginning February 1996 and ending May 2000, and all participants were monetarily compensated, with amounts varying from \$10 to \$20 per interview.

Each study site administered the same semiannual interview assessments measuring demographic characteristics and weekly vocational assessments of employment status. Once enrolled in the study, lack of participation in EIDP services or research interviews were not criteria for exclusion from the study sample. Enrolled participants were randomly assigned to evidence-based supported employment services (i.e., integrated services delivered by employment specialists who were part of multidisciplinary teams that met frequently to coordinate employment and other services, with the goal of placement into competitive jobs that were tailored to patients' career preferences, using a job search process beginning soon after program entry, and providing ongoing vocational supports throughout the entire study period) or to comparison study conditions at each site. The results of the randomized controlled trial regarding the effectiveness of evidence-based supported employment are described elsewhere [26-28].

Data come from 2,086 jobs for which there was information about job ending statuses and reasons. This represents 82 percent of all jobs held. Of the remaining 18 percent, 447 (17\%) were jobs that were ongoing at the end of the observation period and 31 (1\%) were missing job ending information. Job data were collected using the EIDP Common Protocol and Documentation's employment tracking procedures, including job start and end forms completed by program and research staff [24]. Initial assessments of new jobs included detailed information on features such as wages, hours, benefits, job duties, job industry, job setting, job integration, level of contact with disabled and nondisabled coworkers, type of job finding assistance, disclosure of disability status, and job accommodations. This information was updated weekly along with the recording of how many hours were worked that week. Job endings were documented in terms of (1) who made the decision to end the position, (2) ending status classified as voluntary (quit with or without a new position) or involuntary (fired, laid off, temporary job end), and (3) reasons for job ending. Job ending status classifications were compared for consistency with data collected 
on (1) who made the job ending decision (e.g., employee, employer) and (2) reasons for job ending (e.g., poor job performance, dissatisfaction with working conditions). Employment specialists and other program staff received training in how to complete the job end form and a detailed administration manual also provided specific instructions on how to select and code reasons for job endings.

Job data are from 892 study participants who held at least one job that ended during their 24 mo observation period. Characteristics of the 892 individuals included in the job separation analysis were compared with the remainder of the EIDP cohort not included in the present analysis $(n=756)$. Consistent with prior research on predictors of employment in the EIDP [29-30], inclusion in the job separation analysis sample was statistically associated with receiving supported employment services, better prior work history, younger age, and not having a substance abuse diagnosis (univariate chi-square $p<0.05$ ). Otherwise, the group we analyzed did not differ from the larger study population in terms of sex, race and/or ethnicity, number of coresident children, presence of a schizophrenia spectrum or bipolar diagnosis, comorbid medical conditions, self-reported functioning, or Social Security Administration (SSA) disability income beneficiary status (i.e., Supplemental Security Income [SSI] and/or Social Security Disability Insurance [SSDI]).

\section{Measures}

\section{Job Separation}

Separations were categorized as voluntary versus involuntary using definitions from the Bureau of Labor Statistics Job Openings and Labor Turnover Survey [31]. Voluntary separations were defined as job endings in which an individual decided to leave a job, i.e., to quit. Involuntary separations were defined as job endings initiated by the employer, including layoffs with no intent to rehire; discharges because positions were eliminated; discharges resulting from mergers, downsizing, or plant closings; firings or other discharges for cause; terminations of seasonal employees (whether or not they are expected to return next season) and other temporary workers; and layoffs (suspensions from pay status) lasting or expected to last more than 7 days.

\section{Disamenities and Other Job Characteristics}

Job characteristics included in the analysis were hours worked per week, hourly wage, temporary versus permanent job status, fringe benefits (medical or other health insurance, vacation, sick or personal leave), and whether the job was held directly or through an intermediary such as a temporary employment agency or transitional employment program. Occupational category was classified by each site's employment staff using codes from the 1991 Dictionary of Occupational Titles (DOT) published by the U.S. Department of Labor [32]. Also used to characterize each position were DOT Worker Functions codes that rate the complexity of tasks performed by the worker for a particular job. Every job in the DOT is coded according to the way it requires a worker to function in relation to data, people, and things, with a separate digit expressing the worker's relationship to each of these three groups. Occupational categories and Worker Functions codes were verified by researchers against detailed job descriptions provided by vocational staff. Following the work of Böckerman and Ilmakunnas [21], job disamenities included part-time work $(\leq 20 \mathrm{~h} /$ wk), temporary or seasonal jobs, jobs without benefits, and jobs held through intermediaries. In addition, DOT Worker Functions codes were used to identify jobs that were mentally, interpersonally, and physically demanding. Mentally demanding jobs involved working with data by synthesizing, coordinating, analyzing, compiling, or computing (vs copying or comparing). Interpersonally demanding jobs involved mentoring, negotiating, instructing, supervising, diverting, persuading, or giving assignments (vs serving, taking instructions, and helping). Physically demanding jobs involved unloading and direct handling of materials (vs precision operating, driving, tending, and setting up).

\section{Job Dissatisfaction}

Workers' job dissatisfaction was assessed via information contained in employment end forms. For every separation, the primary reason for job termination, as well as additional reasons as reported by the client and/or program staff, were recorded from a checklist of reasons

\footnotetext{
*Unlike Böckerman and Ilmakunnas [21], we were unable to include exclusively worker-perceived job disamenities. This was because workers were not interviewed at the occurrence of each job, but at 6 mo intervals. Thus, while our definition of disamenities met the criterion of being specific to each individual job, most were judged to be disadvantageous by program staff and other objective appraisals such as Worker Functions codes in the DOT [32]. This nonsubjective approach has been used in a number of prior studies of job disamenities [33-35].
} 
related to the worker's psychiatric condition, job performance, job environment, relations with supervisor and coworkers, and ease of access to the job. Job dissatisfaction was assessed by a positive response to one or more of the following reasons: dissatisfaction with physical job environment, dissatisfaction with job duties, problems with supervisor(s), problems with coworkers, dissatisfaction with salary, dissatisfaction with hours, dissatisfaction with work schedule, dissatisfaction with employment benefits, and perceived discrimination.

\section{Worker Characteristics}

Employee characteristics were collected in the baseline EIDP interview, and include age in years, sex (female $=1$ or male $=0$ ), race and/or ethnic group (racial and/or ethnic minority $=1$ or Caucasian $=0)$, educational attainment $(1=$ less than high school or $0=$ otherwise, $1=$ some college or more or $0=$ otherwise), prior work history $(1=$ employed in $5 \mathrm{yr}$ prior to study entry or $0=$ otherwise), marital status ( 1 = married or cohabiting or $0=$ otherwise), and SSA disability program status $(1=$ enrolled in SSDI or SSI or $0=$ not enrolled). Psychiatric diagnoses came from clinical assessments, and in this analysis, we focused on schizophrenia spectrum disorders, bipolar disorder, and substance abuse or dependence.

\section{Labor Market Variables}

Region of the country was used as a proxy for the local unemployment rate. Study sites were clustered in the Northeast, Mid-Atlantic, Southeast, and Southwestern United States. Previous analysis calculated the local unemployment rate for the geographic area surrounding each study site using Bureau of Labor Statistics Current Population Survey reports from January 1996 (first month of study participation for initial group of participants) through November 2000 (last month of study participation for the final group) [36]. Unemployment rates remained fairly consistent over time and were similar by region, allowing us to calculate average regional unemployment rates as a measure of job availability in the local labor market. Average monthly unemployment rates by region were Northeast (3.3\%), Mid-Atlantic (4.7\%), and Southwest (3.4\%), with the Southeast (5.4\%) serving as the contrast.

\section{Statistical Analysis}

Univariate comparisons of factors associated with voluntary versus involuntary job separations were made using chi-square tests of association for categorical dependent variables and analysis of variance for interval or continuous dependent variables. Predictors of voluntary separations were examined in a series of multivariable logistic regressions in which different domains were entered in hierarchical steps: (1) job disamenities, (2) job dissatisfaction, (3) wage, (4) worker characteristics, (5) psychiatric diagnosis, (6) job industry, and (7) geographic region. Absence of multicollinearity was confirmed by the fact that none of the model variables had zero-order correlations $r \geq|0.5|$. There was insufficient clustering of multiple jobs among individuals to support use of multilevel analysis [37]. Instead, data were weighted to reflect the number of jobs contributed by each individual [38].

\section{RESULTS}

While the 892 study participants ended an average of 2.4 jobs each (standard deviation $=1.8$ ) over the $24 \mathrm{mo}$ period, a sizable proportion (41.3\%) ended only one job during this period. Just over half (53.0\%) of all jobs lasted $\leq 2$ mo. Of the 2,086 job separations, over half (59\%) met criteria for voluntary ending or quits. The remainder were involuntary separations: firings (17\%), temporary job endings (14\%), and layoffs (10\%). Job dissatisfaction was the most commonly reported reason for quitting, accounting for 33 percent of all voluntary job separations. Psychiatric disability-related problems were the next most common reason for quitting, including difficulty coping with psychiatric symptoms, hospitalization for mental illness, psychotropic medication problems, and emotional stress, cited in 28 percent of all voluntary job separations. Quitting a job to take another job was the third most common reason but accounted for only 15 percent of voluntary separations. Other reasons for job quits were lack of access to the job or job site (12\%) (e.g., transportation barriers, inability to obtain a reasonable accommodation, or relocation of a business or firm), poor job performance (6\%), and quitting because of concerns about losing disability benefits or entitlements (5\%).

Table 1 presents the characteristics of model variables by domain for the total group of job separations and, separately, by voluntary and involuntary separation status. The majority of positions were part-time at $\leq 20 \mathrm{~h} / \mathrm{wk}$ (66.6\%) and offered no medical or leave benefits (87.9\%). These characteristics did not differ significantly $(p<0.05)$ by voluntary or involuntary separation status. Temporary 
JRRD, Volume 52, Number 4, 2015

Table 1.

Domains and factors associated with voluntary versus involuntary job separations of 2,086 jobs (Employment Intervention Demonstration Program, 1996-2001).

\begin{tabular}{|c|c|c|c|c|}
\hline Domain & $\begin{array}{l}\text { All Separations } \\
\qquad(N=2,086)\end{array}$ & $\begin{array}{l}\text { Voluntary } \\
\text { Separation } \\
(n=1,231)\end{array}$ & $\begin{array}{c}\text { Involuntary } \\
\text { Separation } \\
(n=855)\end{array}$ & $\begin{array}{c}\text { Univariate } \\
\text { Chi-square or } \\
\text { ANOVA } p \text {-Value }\end{array}$ \\
\hline \multicolumn{5}{|l|}{ Step 1: Job Disamenities (\%) } \\
\hline Part-Time ( $\leq 20$ h/wk) & 66.6 & 67.7 & 65.1 & 0.33 \\
\hline Temporary Job & 32.0 & 25.2 & 41.7 & $<0.001$ \\
\hline No Fringe Benefits & 87.9 & 86.9 & 89.3 & 0.09 \\
\hline Interpersonally Demanding & 26.8 & 26.8 & 26.8 & 0.99 \\
\hline Physically Demanding & 75.3 & 75.3 & 75.2 & 0.94 \\
\hline Step 2: Job Dissatisfaction (\%) & 40.0 & 55.3 & 17.9 & $<0.001$ \\
\hline Step 3: Wage $(\$ / h$, mean \pm SD) & $5.77 \pm 2.02$ & $5.62 \pm 1.76$ & $6.00 \pm 2.32$ & $<0.001$ \\
\hline Less Than High School Education (\%) & 31.3 & 31.5 & 31.0 & 0.79 \\
\hline Some College Education or More (\%) & 37.0 & 35.1 & 39.8 & 0.03 \\
\hline Prior 5 yr Work Experience (\%) & 79.0 & 79.5 & 78.2 & 0.49 \\
\hline Married or Living with Partner (\%) & 11.2 & 13.2 & 8.2 & $<0.001$ \\
\hline SSI/SSDI Beneficiary (\%) & 66.6 & 66.0 & 67.4 & 0.49 \\
\hline \multicolumn{5}{|l|}{ Step 5: Clinical Features (\%) } \\
\hline Schizophrenia Spectrum Disorder & 45.6 & 46.1 & 44.9 & 0.58 \\
\hline Bipolar Disorder & 17.6 & 18.4 & 16.5 & 0.27 \\
\hline Substance Abuse and/or Dependence Disorder & 29.4 & 29.1 & 29.9 & 0.67 \\
\hline Northeast & 28.4 & 27.5 & 29.7 & 0.28 \\
\hline Southwest & 38.5 & 37.8 & 39.5 & 0.42 \\
\hline Mid-Atlantic & 18.1 & 17.7 & 18.6 & 0.60 \\
\hline Southeast & 15.0 & 17.0 & 12.2 & 0.002 \\
\hline
\end{tabular}

jobs (32.0\% of all jobs) and jobs held through intermediaries $(22.0 \%$ of all jobs) were associated with less likelihood of voluntary than involuntary separation (25.2\% vs $41.7 \%, p<0.001$, and $18.4 \%$ vs $27.2 \%, p<0.001$, respectively). Jobs were characterized as mentally demanding if they involved synthesizing, coordinating, analyzing, com- piling, or computing (34.8\% of jobs); interpersonally demanding if they involved mentoring, negotiating, instructing, supervising, diverting, persuading, or giving assignments to assistants (26.8\% of jobs); and physically demanding if they involved direct handling or placing of materials with no judgment required (75.3\% of jobs). 
These worker functions were not related to voluntary or involuntary separation status.

Job dissatisfaction was cited in 40.0 percent of all job separations and significantly more often in voluntary than involuntary separations ( $55.3 \%$ vs $17.9 \%, p<0.001$ ). Average hourly wage was $\$ 5.77$, which was above the $\$ 4.25$ to $\$ 5.15$ Federal minimum wage at the time but considerably lower than average U.S. hourly earnings of $\$ 11.87$ to \$14.76 between January 1996 and December 2001 (U.S. Department of Labor Bureau of Labor Statistics: www.data360.org). Average hourly wage was significantly lower among voluntary than involuntary separations (\$5.62 vs $\$ 6.00, p<0.001$ ).

Voluntary and involuntary job separations did not differ significantly by worker sex (women held $44.1 \%$ of all jobs), racial and/or ethnic minority (50.5\%), less than high school education (31.3\%), any work experience in the $5 \mathrm{yr}$ prior to EIDP participation (79.0\%), or enrollment in SSI and/or SSDI programs (66.6\%). However, younger workers and those who were married or living with a partner were more likely to quit, while workers with any college education were less likely to quit. There were significant differences in voluntary versus involuntary separation associated with average age (35.9 vs $37.3 \mathrm{yr}, p=0.001$ ), being married or cohabiting with a partner $(13.2 \%$ vs $8.2 \%, p<0.001)$, and any college education $(35.1 \%$ vs $39.8 \%, p=0.03$ ). DSM-IV diagnosis did not vary significantly by job separation status, with 45.6 percent of jobs held by people diagnosed with schizophrenia spectrum disorders, 17.6 percent with bipolar disorder, and 29.4 percent with a substance use or dependence disorder.

Almost half of all jobs (44.0\%) were in service industry occupations, 25.4 percent clerical and sales, 4.4 percent professional, 4.4 percent structural (construction), and 4.0 percent benchwork. The remaining 18 percent of jobs were in the categories of miscellaneous occupations (13\%); agricultural, fisher, and/or forestry (3\%); processing occupations (1\%); and machine trades (1\%). Service occupation jobs were more often associated with voluntary rather than involuntary separations ( $46.4 \%$ vs $40.6 \%, p=0.01$ ), but the reverse was true for clerical and sales jobs (23.7\% vs $27.8 \%, p=0.04)$.

In terms of geographic region, 28.4 percent of jobs were in the Northeast (Maine, New Hampshire, New York), 38.5 percent in the Mid-Atlantic region (Maryland, Pennsylvania), 18.1 percent in the Southwest (Arizona, Texas), and 15.0 percent in the Southeast (South Carolina). Job separation status did not differ by geo- graphic region except in the Southeast, which had a higher proportion of voluntary job endings $(17.0 \%$ vs $12.2 \%, p=0.002$ ).

Table 2 presents the results of a stepped logistic regression model predicting voluntary separations or quits versus involuntary job endings. Step 1 involved entering seven hypothesized job disamenities. Individuals were more likely to quit part-time positions worked for $\leq 20 \mathrm{~h} /$ wk than positions with a greater number of hours per week. They were less likely to quit jobs that were temporary versus jobs with no predefined end point. There were no relationships between quitting and whether the job conferred employee benefits or whether the job was held through an intermediary versus a direct relationship with the employer. Finally, there was no relationship between voluntary separation and the nature of the job as physically, mentally, or interpersonally demanding.

In step 2, job dissatisfaction was entered. As predicted, this variable was significant, with dissatisfied workers over five times as likely to quit their jobs as nondissatisfied workers. Both working $\leq 20 \mathrm{~h} / \mathrm{wk}$ and temporary job status remained significant in this step.

In step 3, hourly wage was entered into the model. As predicted, this variable was significant, with quitting less likely when jobs a paid higher hourly wage than when they paid a lower wage. All variables significant in previous steps remained significant even controlling for hourly wage.

In step 4, worker characteristics were entered into the model, and two of these were significant. First, older workers were significantly less likely to quit their jobs than younger workers. Second, workers who were married or cohabiting were over 1.5 times as likely to quit their positions as workers who were single.

In step 5, the worker's clinical characteristics were entered. Neither mental health diagnosis nor whether the worker had a substance abuse or dependence diagnosis were significant additions to the model. Moreover, controlling for these factors did not alter the significance of variables entered in prior steps.

In step 6, the occupational designation of positions was entered. Here, structural positions, typically construction jobs, were almost three times as likely to end in quitting as other types of occupations. All variables significant in prior steps remained significant.

Finally, in step 7, region was entered as a proxy for unemployment rate, based on the regions of the United States in which study sites were located. Here, voluntary separation was more likely in regions with lower average 
JRRD, Volume 52, Number 4, 2015

Table 2.

Antecedents of 2,086 job separations with domains entered in hierarchical multivariable logistic regression models predicting voluntary versus involuntary separation (Employment Intervention Demonstration Program, 1996-2001).

\begin{tabular}{|c|c|c|c|c|c|c|c|}
\hline \multirow{2}{*}{ Domain } & \multicolumn{7}{|c|}{ Multivariable Logistic Regression Odds Ratio } \\
\hline & Step 1 & Step 2 & Step 3 & Step 4 & Step 5 & Step 6 & Step 7 \\
\hline \multicolumn{8}{|l|}{ Step 1: Job Disamenities } \\
\hline Part-Time $(\leq 20 \mathrm{~h} / \mathrm{wk})$ & $1.41^{*}$ & $1.49^{\dagger}$ & $1.46^{\dagger}$ & $1.47^{\dagger}$ & $1.46^{\dagger}$ & $1.48^{\dagger}$ & $1.47^{\dagger}$ \\
\hline Temporary Job & $0.54^{*}$ & $0.58^{\dagger}$ & $0.60^{\dagger}$ & $0.61^{\dagger}$ & $0.62^{\dagger}$ & $0.61^{\dagger}$ & $0.54^{\dagger}$ \\
\hline No Fringe Benefits & 0.80 & 0.83 & 0.80 & 0.80 & 0.80 & 0.78 & 0.85 \\
\hline Job Held Through Intermediary & 0.83 & 0.98 & 0.90 & 0.91 & 0.90 & 0.94 & 0.91 \\
\hline Mentally Demanding & 1.01 & 1.04 & 1.10 & 1.07 & 1.08 & 1.17 & 1.18 \\
\hline Interpersonally Demanding & 0.95 & 0.95 & 0.98 & 1.03 & 1.03 & 1.23 & 1.19 \\
\hline Physically Demanding & 1.06 & 1.05 & 1.04 & 1.04 & 1.03 & 1.15 & 1.14 \\
\hline Step 2: Job Dissatisfaction & - & $5.46^{*}$ & $5.40^{*}$ & $5.50^{*}$ & $5.47^{*}$ & $5.55^{*}$ & $5.82^{*}$ \\
\hline Step 3: Wage (hourly wage, $\$ 0.10$ increments) & - & - & $0.39^{\ddagger}$ & $0.40^{\ddagger}$ & $0.40^{\ddagger}$ & $0.36^{\dagger}$ & $0.40^{\ddagger}$ \\
\hline \multicolumn{8}{|l|}{ Step 4: Worker Characteristics } \\
\hline Age & - & - & - & $0.91^{\ddagger}$ & $0.91^{\ddagger}$ & $0.91^{\ddagger}$ & $0.91^{\ddagger}$ \\
\hline Female & - & - & - & 1.24 & 1.26 & $1.33^{\S}$ & 1.24 \\
\hline Racial and/or Ethnic Minority & - & - & - & 0.81 & 0.81 & $0.79^{\S}$ & $0.69^{\ddagger}$ \\
\hline Less Than High School Education & - & - & - & 1.08 & 1.10 & 1.07 & 1.04 \\
\hline Some College Education or More & - & - & - & 0.85 & 0.84 & 0.87 & 0.87 \\
\hline Prior 5 yr Work Experience & - & - & - & 0.95 & 0.97 & 0.96 & 0.96 \\
\hline Married or Living with Partner & - & - & - & $1.75^{\ddagger}$ & $1.72^{\ddagger}$ & $1.72^{\ddagger}$ & $1.61^{\ddagger}$ \\
\hline SSI/SSDI Beneficiary & - & - & - & 1.06 & 1.05 & 1.06 & 1.04 \\
\hline \multicolumn{8}{|l|}{ Step 5: Clinical Features } \\
\hline Schizophrenia Spectrum Disorder & - & - & - & - & 1.13 & 1.14 & 1.22 \\
\hline Bipolar Disorder & - & - & - & - & 1.13 & 1.13 & 1.15 \\
\hline Substance Abuse and/or Dependence Disorder & - & - & - & - & 0.91 & 0.90 & 0.91 \\
\hline \multicolumn{8}{|l|}{ Step 6: Occupational Category } \\
\hline Service & - & - & - & - & - & 1.13 & 1.17 \\
\hline Clerical/Sales & - & - & - & - & - & 0.84 & 0.97 \\
\hline Professional & - & - & - & - & - & 0.84 & 0.94 \\
\hline Structural/Construction & - & - & - & - & - & $2.83^{\ddagger}$ & $2.79^{\ddagger}$ \\
\hline Benchwork & - & - & - & - & - & 1.43 & 1.38 \\
\hline \multicolumn{8}{|l|}{ Step 7: Region } \\
\hline Northeast & - & - & - & - & - & - & $0.47^{\dagger}$ \\
\hline Mid-Atlantic & - & - & - & - & - & - & $0.57^{\ddagger}$ \\
\hline Southwest & - & - & - & - & - & - & $0.42^{\ddagger}$ \\
\hline Southeast & - & - & - & - & - & - & Ref \\
\hline 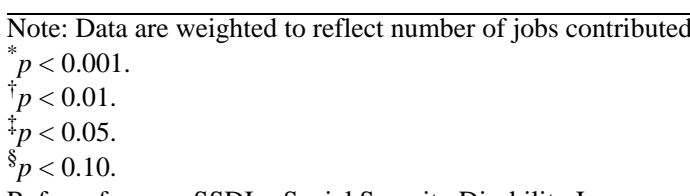 & each indi & & & & & & \\
\hline
\end{tabular}

unemployment rates in comparison with the Southeast, which had the highest average unemployment rate. Significance of variables entered in prior steps did not change, with the exception of worker's racial and/or ethnic minority status, which became significantly related to lesser likelihood of quitting.

\section{DISCUSSION}

Many of our findings regarding voluntary separation of workers with psychiatric disabilities mirrored those derived from research on the general population. We found a strong association between job dissatisfaction and 
the likelihood of quitting that was first established in the human resource literature. Another example is our finding of an association between low-wage labor and greater likelihood of voluntary separation that was previously established in labor economics research. Still another similarity is our finding that married or cohabiting workers were more likely to quit than single workers. This may have reflected the former's ability to rely on a spouse or partner's human capital during periods of unemployment after voluntary separations, as others have found [39]. Another similar pattern was our finding that compared with older workers, younger workers who presumably had lower labor force attachment were more likely to voluntarily separate from their jobs. We also found that in comparison with Caucasian workers, minority workers were less likely to quit, which may reflect the latter's more precarious labor market opportunities and position. Finally, we found that workers were more likely to quit part-time jobs than ones providing more hours of compensation, as would be predicted given the risk and instability inherent in part-time labor.

Other findings did not mirror those found in research on general labor force separation patterns. For example, we expected to see greater likelihood of quitting in regions with lower unemployment rates. Instead, we found that voluntary separation was more likely at study sites in the Northeast, Mid-Atlantic, and Southwest, all of which had lower average monthly unemployment rates than our reference region of the Southeast. It may be that our proxy for unemployment was too gross a measure and that some other features of these regions influenced quit likelihood. Also unexpectedly, we found that workers were less likely to quit jobs that were temporary versus those with indefinite tenures. This was contrary to the hypothesis that temporary employment would be perceived unfavorably by workers who would be seeking more permanent, stable employment. This may not be the case for workers with disabilities, who may need or prefer the flexibility of nonpermanent positions [40]. A similar rationale may apply to our finding of higher voluntary separation likelihood for jobs in the structural (construction) industries, occupations known for their required "presenteeism" and "infinite availability" [41], which may be a poor match for the needs and stamina of some workers with psychiatric disabilities [42], such as veterans who may have co-occurring physical injuries and impairments [43].

Overall, we found limited support for Böckerman and Ilmakunnas' job disamenities hypothesis [21], since only two of the seven unfavorable conditions we tested were significant in our model, and one of these relationships (temporary employment) was in an unexpected direction. This may mean that the concept of work disamenities has limited relevance for this group of disabled workers. Or it may be because, unlike those authors, we measured adverse work conditions with primarily objective rather than subjective job-specific variables. It is also worth noting that Böckerman and Ilmakunnas' own research did not find a strong relationship between disamenities and actual quitting [21]. Instead, they found that disamenities were more strongly related to job quit intentions than to actual behavior. Their findings suggested that disamenities influence job satisfaction, which in turn increases quit intentions that increase the likelihood of actual quit behavior. Because we were unable to assess quit intentions, our inability to test that specific chain of associations leaves open the question of the relative import of disamenities to voluntary separation for our population of interest.

The fact that certain client characteristics such as education and prior work experience were not related to the likelihood of voluntary separation may be the result of labor segmentation that these workers experienced. As others have shown [44-45], compared with primary sector workers, workers with disabilities in the secondary labor market receive a lower return on education and their labor force participation does not offer the same opportunities for advancement. Thus, the value of human capital may be less for these workers, as has been argued by others [46-47].

Consistent with the limited prior research, very few of the 2,086 jobs ended with workers moving on to another job. A high proportion of people with psychiatric disabilities quit due to job dissatisfaction, which is likely a reflection of their typical underemployment or employment in poor-quality jobs [48]. In the EIDP, lower-wage jobs were significantly associated with greater likelihood of workers voluntarily separating from jobs versus being involuntarily separated. In addition, only 5 percent of voluntary job separations were attributed to concern over loss of benefits, and SSI and/or SSDI beneficiary status was not associated with greater likelihood of quitting. This suggests that workers were not highly concerned about loss of cash benefits due to employment, most likely because low earnings and short job tenures generally did not reach levels at which benefits would be reduced or terminated due to Substantial Gainful Activity or completion of Trial Work Periods [49]. 
While it was not common, some workers with psychiatric disabilities did leave their jobs voluntarily in order to take other, more preferable employment that they had secured ahead of time. Yet given that this was a relatively infrequent occurrence, it may be that job retention support specific to keeping one position should be redefined as employment retention assistance, helping workers to transition smoothly between jobs either to pursue career development or satisfy other life choices. Our results also suggest the need for job follow-along services that focus on career enhancement for workers in the secondary labor market [50]. Since market segmentation research suggests that these workers will acquire few transferrable skills, job-related training, or opportunities for advancement, ongoing support should include regular screening of jobs for advancement opportunities and assessment of workers' needs for further training and education that would enable them to obtain jobs in the primary labor market [51]. Rumrill and Roessler suggest that at 6 and 12 mo intervals following job placement, rehabilitation counselors could conduct structured interviews with employed rehabilitation clients to obtain valuable information to consider in this effort [51].

A number of caveats should be mentioned in regard to our study findings. First, we did not examine a nationally representative sample of adults with psychiatric disabilities; thus, our results cannot necessarily be generalized to this group. Second, the study population consisted of paid volunteer subjects who were interested in working, which may not be representative of the broader population of individuals with psychiatric disabilities. Third, as previously mentioned, we were unable to measure job disamenities using subjective, job-specific ratings from the perspectives of workers themselves, which may have led to different results. Fourth, it is possible that unmeasured, underlying demographic characteristics of the study sample may be contributing to the effect of region that we found, and our data do not allow us to explore this possibility. Fifth, data reported by employment specialists on reasons for job separation may have been biased in certain ways, even given the training they received and the detailed instructions for Job End Form completion in the study's administration manual. Sixth, data were collected during the late 1990s and early 2000s and different results might have been obtained in today's economy. Finally, we were unable to control for the potential influence of employment specialists on participant outcomes, while factors such as employment specialist competency, experi- ence, caseload size, and job performance quality may have influenced the likelihood of job separations.

\section{CONCLUSIONS}

Our study results have important implications for return-to-work efforts among the general population of working-age adults with psychiatric disabilities served by the state-Federal vocational rehabilitation system [52], as well as those served by the Department of Veterans Affairs Veterans Benefits Administration's Vocational Rehabilitation and Employment (VR\&E) service [43]. The VR\&E service currently provides employment services to an estimated 4.2 percent of veterans with psychiatric disabilities, including supported employment [53], and evidence demonstrates these services' effectiveness [54]. Our results support a vocational rehabilitation focus on enhancing workers' job satisfaction, helping them secure better paid positions, and providing them with career-building services even after employment to help them keep working or return more easily to work after separation from a job.

\section{ACKNOWLEDGMENTS}

\section{Author Contributions:}

Study concept and design: J. A. Cook.

Acquisition of data: J. A. Cook.

Analysis and interpretation of data: J. A. Cook, J. K. Burke-Miller.

Drafting of manuscript: J. A. Cook, J. K. Burke-Miller.

Critical revision of manuscript for important intellectual content:

J. A. Cook, J. K. Burke-Miller.

Statistical analysis: J. K. Burke-Miller.

Obtained funding: J. A. Cook.

Administrative, technical, or material support: J. K. Burke-Miller. Study supervision: J. A. Cook.

Financial Disclosures: The authors have declared that no competing interests exist.

Funding/Support: This material was based on work supported by a grant from the SSA, funded as part of the Disability Research Consortium (Cooperative Agreement 1-DRC12000001-01-00) with Mathematica Policy Research Inc. Data come from the EIDP, funded by the SAMHSA/CMHS (Cooperative Agreement SM51820). Ongoing dissemination is funded by the National Institute on Disability, Independent Living, and Rehabilitation Research (NIDILRR) and the CMHS/ SAMHSA (grant 90 RT5012-01-00). NIDILRR is a center within the Administration for Community Living, U.S. Department of Health and Human Services.

Institutional Review: Informed consent and other research procedures were reviewed and approved by the UIC Institutional Review Board (IRB) as well as the IRBs of all participating study sites. 
Disclaimer: The opinions and conclusions expressed are solely those of the authors and do not represent the opinions or policy of the SSA or any agency of the Federal Government. Neither the U.S. Government nor any agency thereof, nor any of their employees, makes any warranty, expressed or implied, or assumes any legal liability or responsibility for the accuracy, completeness, or usefulness of the contents of this report. Reference herein to any specific commercial product, process, or service by trade name, trademark, manufacturer, or otherwise does not necessarily constitute or imply endorsement, recommendation, or favoring by the U.S. Government or any agency thereof.

\section{REFERENCES}

1. Cook JA, Burke J. Public policy and employment of people with disabilities: Exploring new paradigms. Behav Sci Law. 2002;20(6):541-57. [PMID:12465127]

http://dx.doi.org/10.1002/bsl.515

2. Leff HS, Cook JA, Gold PB, Toprac M, Blyler C, Goldberg RW, McFarlane W, Shafer M, Allen IE, CamachoGonsalves T, Raab B. Effects of job development and job support on competitive employment of persons with severe mental illness. Psychiatr Serv. 2005;56(10):1237-44.

[PMID:16215189]

http://dx.doi.org/10.1176/appi.ps.56.10.1237

3. Resnick SG, Neale MS, Rosenheck RA. Impact of public support payments, intensive psychiatric community care, and program fidelity on employment outcomes for people with severe mental illness. J Nerv Ment Dis. 2003;191(3): 139-44. [PMID:12637839] http://dx.doi.org/10.1097/01.NMD.0000054991.62302.60

4. Cook JA. Job ending among youth and adults with severe mental illness. J Ment Health Adm. 1992;19(2):158-69. [PMID:10121508] http://dx.doi.org/10.1007/BF02521316

5. Becker DR, Drake RE, Bond GR, Xie H, Dain BJ, Harrison K. Job terminations among persons with severe mental illness participating in supported employment. Community Ment Health J. 1998;34(1):71-82. [PMID:9559241] http://dx.doi.org/10.1023/A:1018716313218

6. Bond GR, Resnick SG, Drake RE, Xie H, McHugo GJ, Bebout RR. Does competitive employment improve nonvocational outcomes for people with severe mental illness? J Consult Clin Psychol. 2001;69(3):489-501. [PMID:11495178] http://dx.doi.org/10.1037/0022-006X.69.3.489

7. Evans J, Repper J. Employment, social inclusion and mental health. J Psychiatr Ment Health Nurs. 2000;7(1):15-24. [PMID:11022507] http://dx.doi.org/10.1046/j.1365-2850.2000.00260.x

8. Schofield DJ, Shrestha RN, Percival R, Passey ME, Callander EJ, Kelly SJ. The personal and national costs of mental health conditions: Impacts on income, taxes, gov- ernment support payments due to lost labour force participation. BMC Psychiatry. 2011;11:72. [PMID:21526993]

http://dx.doi.org/10.1186/1471-244X-11-72

9. Stewart WF, Ricci JA, Chee E, Hahn SR, Morganstein D. Cost of lost productive work time among US workers with depression. JAMA. 2003;289(23):3135-44. [PMID:12813119] http://dx.doi.org/10.1001/jama.289.23.3135

10. Mak DC, Tsang HW, Cheung LC. Job termination among individuals with severe mental illness participating in a supported employment program. Psychiatry. 2006;69(3): 239-48. [PMID:17040175] http://dx.doi.org/10.1521/psyc.2006.69.3.239

11. Gates LB, Klein SW, Akabas SH, Myers R, Schawager M, Kaelin-Kee J. Outcomes-based funding for vocational services and employment of people with mental health conditions. Psychiatr Serv. 2005;56(11):1429-35. [PMID:16282263] http://dx.doi.org/10.1176/appi.ps.56.11.1429

12. Wong KK, Chiu SN, Chiu LP, Tang SW. A supported competitive employment programme for individuals with chronic mental illness. Hong Kong J Psychiatry. 2001; 11(2):13-18.

13. Berger S, Piore M. Dualism and discontinuity in industrial society. Cambridge (United Kingdom): Cambridge University Press; 1980.

14. Bernstein J, Hartmann H. Defining and characterizing the low-wage labor market. In: Kaye K, Nightingale DS, editors. The low-wage labor market: Challenges and opportunities for economic self-sufficiency. Washington (DC): U.S. Department of Health and Human Services, Urban Institute Press; 2000. p. 14-40.

15. Autor DH, Dorn D. The growth of low-skill service jobs and the polarization of the US labor market. Am Econ Rev. 2013;103(5):1553-97. http://dx.doi.org/10.1257/aer.103.5.1553

16. Catalano R, Drake RE, Becker DR, Clark RE. Labor market conditions and employment of the mentally ill. J Ment Health Policy Econ. 1999;2(2):51-54. [PMID:11967408]

17. Shafer MS, Banks PD, Kregel J. Employment retention and career movement among individuals with mental retardation working in supported employment. Ment Retard. 1991; 29(2):103-10. [PMID:1861619]

18. Lane J. The role of job turnover in the low-wage labor market. In: Kaye K, Nightingale DS, editors. The low-wage labor market: Challenges and opportunities for economic selfsufficiency. Washington (DC): U.S. Department of Health and Human Services, Urban Institute Press; 2000. p. 185-98.

19. Kaye K, Nightingale DS, editors. The low-wage labor market: Challenges and opportunities for economic self-sufficiency. Washington (DC): U.S. Department of Health and Human Services, Urban Institute Press; 2000. 
20. Böckerman P, Ilmakunnas P. Do job disamenities raise wages or ruin job satisfaction? Int J Manpow. 2006;27(3): 290-302. http://dx.doi.org/10.1108/01437720610672185

21. Böckerman P, Ilmakunnas P. Job disamenities, job satisfaction, quit intentions, and actual separations: Putting the pieces together. Ind Relat. 2009;48:73-96.

http://dx.doi.org/10.1111/j.1468-232X.2008.00546.x

22. Cook JA, Razzano LA, Burke-Miller JK, Blyler CR, Leff HS, Mueser KT, Gold PB, Goldberg RW, Shafer MS, Onken SJ, McFarlane WR, Donegan K, Carey MA, Kaufmann C, Grey DD. Effects of co-occurring disorders on employment outcomes in a multisite randomized study of supported employment for people with severe mental illness. J Rehabil Res Dev. 2007;44(6):837-49. [PMID:18075941] http://dx.doi.org/10.1682/JRRD.2006.07.0079

23. Cook JA, Blyler CR, Leff HS, McFarlane WR, Goldberg RW, Gold PB, Mueser KT, Shafer MS, Onken SJ, Donegan K, Carey MA, Kaufmann C, Razzano LA. The employment intervention demonstration program: Major findings and policy implications. Psychiatr Rehabil J. 2008;31(4): 291-95. [PMID:18407877]

http://dx.doi.org/10.2975/31.4.2008.291.295

24. Employment Intervention Demonstration Program [Internet]. Common protocol and documentation. Chicago (IL): Center on Mental Health Services Research and Policy, Department of Psychiatry, University of Illinois at Chicago; 2001. Available from:

http://www.psych.uic.edu/eidp/eidpdocs.htm

25. American Psychiatric Association. Diagnostic and statistical manual of mental disorders: DSM-IV-TR. Washington (DC): American Psychiatric Association; 2000.

26. Cook JA, Leff HS, Blyler CR, Gold PB, Goldberg RW, Mueser KT, Toprac MG, McFarlane WR, Shafer MS, Blankertz LE, Dudek K, Razzano LA, Grey DD, BurkeMiller J. Results of a multisite randomized trial of supported employment interventions for individuals with severe mental illness. Arch Gen Psychiatry. 2005;62(5): 505-12. [PMID:15867103] http://dx.doi.org/10.1001/archpsyc.62.5.505

27. Cook JA, Lehman AF, Drake R, McFarlane WR, Gold PB, Leff HS, Blyler C, Toprac MG, Razzano LA, Burke-Miller JK, Blankertz L, Shafer M, Pickett-Schenk SA, Grey DD. Integration of psychiatric and vocational services: A multisite randomized, controlled trial of supported employment. Am J Psychiatry. 2005;162(10):1948-56.

[PMID:16199843]

http://dx.doi.org/10.1176/appi.ajp.162.10.1948

28. Cook JA, Blyler CR, Burke-Miller JK, Macfarlane WR, Leff HS, Mueser KT, Gold PB, Goldberg RW, Shafer MS, Onken SJ, Donegan K, Carey MA, Razzano LA, Grey DD, Pickett-Schenk SA, Kaufmann C. Effectiveness of sup- ported employment for individuals with schizophrenia: Results of a multi-site, randomized trial. Clin Schizophr Relat Psychoses. 2008;2(1):37-46.

http://dx.doi.org/10.3371/CSRP.2.1.2

29. Burke-Miller JK, Cook JA, Grey DD, Razzano LA, Blyler CR, Leff HS, Gold PB, Goldberg RW, Mueser KT, Cook WL, Hoppe SK, Stewart M, Blankertz L, Dudek K, Taylor AL, Carey MA. Demographic characteristics and employment among people with severe mental illness in a multisite study. Community Ment Health J. 2006;42(2):143-59. [PMID:16404685] http://dx.doi.org/10.1007/s10597-005-9017-4

30. Razzano LA, Cook JA, Burke-Miller JK, Mueser KT, Pickett-Schenk SA, Grey DD, Goldberg RW, Blyler CR, Gold PB, Leff HS, Lehman AF, Shafer MS, Blankertz LE, McFarlane WR, Toprac MG, Ann Carey M. Clinical factors associated with employment among people with severe mental illness: Findings from the employment intervention demonstration program. J Nerv Ment Dis. 2005;193(11): 705-13. [PMID:16260923]

http://dx.doi.org/10.1097/01.nmd.0000185939.11282.3e

31. Bureau of Labor Statistics. Job openings and labor turnover survey [Internet]. Washington (DC): U.S. Department of Labor; 2013. Available from:

http://www.bls.gov/jlt/jltdef.htm\#4.\%3C/eref

32. Inter-university Consortium for Political and Social Research. Dictionary of occupational titles (DOT): Revised fourth edition, 1991 (ICPSR 6100) [Internet]. Ann Arbor (MI): Institute for Social Research, University of Michigan; 1994. Available from:

http://www.icpsr.umich.edu/icpsrweb/ICPSR/studies/6100/ version $/ 1$

33. Gronberg TJ, Reed WR. Estimating workers' marginal willingness to pay for job attributes using duration data. J Hum Resour. 1994;29:911-31. http://dx.doi.org/10.2307/146258

34. Herzog HW, Schottmann AM. Valuing risk in the workplace: Market price, willingness to pay, and the optimal provision of safety. Rev Econ Stat. 1990;72:463-70. http://dx.doi.org/10.2307/2109354

35. Bartel AP. Wages, nonwage job characteristics, and labor mobility. Ind Labor Relat Rev. 1982;35:578-89. http://dx.doi.org/10.2307/2522669

36. Cook JA, Mulkern G, Grey D, Burke-Miller J, Blyler C, Razzano L, Onken SJ, Balser RM, Gold P, Shafer M, Kaufmann C, Donegan K, Chow C, Steigman P. Effects of local unemployment rate on vocational outcomes in a randomized trial of supported employment for individuals with psychiatric disabilities. J Vocat Rehabil. 2006;25(2): 71-84.

37. Clarke P. When can group level clustering be ignored? Multilevel models versus single-level models with sparse 
data. J Epidemiol Community Health. 2008;62(8):752-58. [PMID:18621963]

http://dx.doi.org/10.1136/jech.2007.060798

38. Lehtonen R, Pahkinen E. Practical methods for design and analysis of complex surveys. Chichester (NY): Wiley; 1995.

39. Shaw KL. The quit propensity of married men. J Labor Econ. 1987;5(4):533-60. http://dx.doi.org/10.1086/298160

40. Booth AL, Francesconi M, Frank J. Temporary jobs: Stepping stones or dead ends? Econ J. 2002;112(480):F189-213. http://dx.doi.org/10.1111/1468-0297.00043

41. Watts JH. 'Allowed into a man's world' meanings of worklife balance: Perspectives of women civil engineers as 'minority' workers in construction. Gend Work Organ. 2009; 16(1):37-57. http://dx.doi.org/10.1111/j.1468-0432.2007.00352.x

42. Baron RC, Salzer MS. Accounting for unemployment among people with mental illness. Behav Sci Law. 2002; 20(6):585-99. [PMID:12465129] http://dx.doi.org/10.1002/bsl.513

43. Frain MP, Bethel M, Bishop M. A roadmap for rehabilitation counseling to serve military veterans with disabilities. J Rehabil. 2010;76(1):13-21.

44. Dickens W, Lang K. A test of dual market theory. Am Econ Rev. 1985;75:792-805.

45. Sakamoto A, Chen MD. Further evidence on returns to schooling by establishment size. Am Sociol Rev. 1991; 56(6):765-71. http://dx.doi.org/10.2307/2096254

46. Aakvik A. Estimating the employment effects of education for disabled workers in Norway. Empir Econ. 2003; 28(3):515-33. http://dx.doi.org/10.1007/s001810200143

47. Hollenbeck K, Kimmel J. Differences in the returns to education for males by disability status and age of disability onset. South Econ J. 2008;74(3):707-24.

48. Cook JA. Employment barriers for persons with psychiatric disabilities: Update of a report for the President's Commission. Psychiatr Serv. 2006;57(10):1391-1405. [PMID:17035556] http://dx.doi.org/10.1176/ps.2006.57.10.1391

49. Cook JA, Leff HS, Blyler CR, Gold PB, Goldberg RW, Clark RE, Onken SJ, Shafer MS, Blankertz LE, McFarlane WR, Razzano LA, Burke-Miller JK. Estimated payments to employment service providers for persons with mental ill- ness in the Ticket to Work program. Psychiatr Serv. 2006; 57(4):465-71. [PMID:16603740]

http://dx.doi.org/10.1176/ps.2006.57.4.465

50. Hagner D. Primary and secondary labor markets: Implications for vocational rehabilitation. Rehabil Couns Bull. 2000;44(1):22-29.

http://dx.doi.org/10.1177/003435520004400104

51. Rumrill PD, Roessler RT. New directions in vocational rehabilitation: A "career development" perspective on “closure.” J Rehabil. 1999;65(1):26-30.

52. Stapleton DC, O’Day BL, Livermore GA, Imparato AJ. Dismantling the poverty trap: Disability policy for the twenty-first century. Milbank Q. 2006;84(4):701-32. [PMID:17096639] http://dx.doi.org/10.1111/j.1468-0009.2006.00465.x

53. Abraham KM, Ganoczy D, Yosef M, Resnick SG, Zivin K. Receipt of employment services among Veterans Health Administration users with psychiatric diagnoses. J Rehabil Res Dev. 2014;51(3):401-14. [PMID:25019663] http://dx.doi.org/10.1682/JRRD.2013.05.0114

54. Leddy M, Stefanovics E, Rosenheck R. Health and wellbeing of homeless veterans participating in transitional and supported employment: Six-month outcomes. J Rehabil Res Dev. 2014;51(1):161-75. [PMID:24805902] http://dx.doi.org/10.1682/JRRD.2013.01.0011

Submitted for publication October 26, 2014. Accepted in revised form February 25, 2015.

This article and any supplementary material should be cited as follows:

Cook JA, Burke-Miller JK. Reasons for job separations in a cohort of workers with psychiatric disabilities. J Rehabil Res Dev. 2015;52(4):371-84.

http://dx.doi.org/10.1682/JRRD.2014.10.0260

ResearcherID: Judith A. Cook, PhD: B-9107-2013

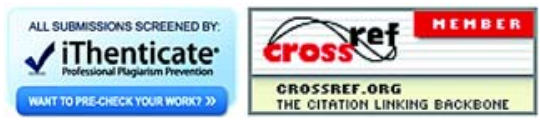


